\title{
Meta Analisis Efektifitas Model Pembelajaran Teams Games Tournament (TGT) Dan Model Pembelajaran Numbered Head Together (NHT) Terhadap Peningkatan Keterampilan Kolaborasi Siswa Sekolah Dasar
}

\author{
${ }^{1}$ Bella Karmila, ${ }^{2}$ Mawardi \\ ${ }^{12}$ Pendidikan Guru Sekolah Dasar UKSW \\ E-mail : 292016131@student.uksw.edu, Mawardi@uksw.edu
}

\begin{abstract}
Abstrak: Jenis penelitian ini menggunakan penelitian Meta Analisis, penelitian ini bertujuan untuk mengetahui ada tau tidaknya pengaruh antara model pembelajaran TGT dan NHT dalam meningkatkan keterampilan kolaborasi pada siswa Sekolah Dasar. Teknik yang digunakan adalah analisis Teknik Effect Size dengan rumus effect size yang digunakan formula pengeruh dengan rumus eta kuadrat (ท́2). Instrumen yang digunakan peneliti dalam penelitian ini insrtumen pemberian koding (coding data). variabel yang digunakan dalam memperoleh informasi mengenai besar pengaruh (effect size) penelitian meta-analisis. Dari hasil penelitian yang dilakukan menunjukan hasil model pembelajaran TGT lebih efetif dibandingankan dengan model pembelajaran NHT terhadap peningkatan keterampilan kolaborasi siswa. Dilihat dari Uji Ancova dari nilai rata-rata eksperimen 2 model pembelajaran TGT memperoleh nilai sebesar 85.3675 lebih tinggi jika dibandingkan dengan niali dari model pembelajaran NHT dengan nilai sebesar 63.7313. Dari hasil perhitungan Hipotesis menggunakan uji Ancova dengan menggunakan Univariate menunjukan nilai Signifikansi sebesar 0,016 yang berarti lebih kecil dari 0,05 $(0,016<0,05)$. Dari uji Ancova menunjukan $\mathrm{f}$ hitung $>\mathrm{f}$ tabel sebesar 0,016 dan f hitung yang diperoleh 10,885, menujukan bahwa 10,885>5,79 dan signifikansinya $0,016<0,05$ yang menujukan bahwa Ho ditolak dan Ha diterima. Dari hasil uji ini menunjukan bahwa terdapat perbedaan yang signifikansi dalam penggunaan model pembelajaran TGt dan NHT dalam peningkatan keterampilan kolaborasi siswa.
\end{abstract}

Kata Kunci: Meta Analisis, Teams Games Tournament, Numbered Head Together, Kolaborasi.

Abstract: This type of research uses Meta-analysis research, this study aims to determine whether or not there is an influence between the TGT and NHT learning models in improving collaboration skills in elementary school students. The technique used is the Effect Size Technique analysis with the effect size formula, which is used as a clouding formula with the eta squared (i2) formula. The instrument used by researchers in this study was an instrument for coding (coding data). variables used in obtaining information about the effect size of the meta-analysis research. From the results of the research conducted, it shows that the results of the TGT learning model are more effective than the NHT learning model on improving student collaboration skills. Judging from the Ancova test from the average value of the experiment 2, the TGT learning model obtained a value of 85.3675 which was higher than the value of the NHT learning model with a value of 63.7313. From the results of the calculation of the hypothesis using the Ancova test using Univariate shows a significance value of 0.016, which means less than 0.05 (0.016 <0.05). From the Ancova test, it shows that $f$ count $>$ f table is 0.016 and f count is 10.885 , indicating that $10.885>5.79$ and the significance is $0.016<0.05$, which indicates that Ho is rejected and Ha is accepted. The results of this test show that there are significant differences in the use of the TGT and NHT learning models in improving student collaboration skills.

Keywords: Meta-Analysis, Teams Games Tournament, Numbered Head Together, Collaboration.

\section{PENDAHULUAN}

Permendikbud RI nomor 20 tahun 2016 tentang kompetensi Inti dan Kompetensi Dasar dalam pembelajaran Kurikulum 2013 mengatakan bahwa Pendidikan Dasar dan Menengah sudah melaksakan pembelajaran dengan menerapkan pembelajaran tematik terpadu. Pendidikan merupakan suatu tempat 
yang didalamnya terdiri atas guru dan peserta didik, yang melakukan proses pembelajaran. Tujuan dari sistem Pendidikan untuk mengembangkan potensi peserta didik menjadi manusia beriman dan bertakwa kepada Tuhan Yang Maha Esa, berakhlak mulia, kreatif, serta menjadi manusia yang bertanggung jawab.

Pembelajaran tematik merupakan program pembelajaran yang berangkat dari satu tema atau topik tertentu dan kemudian dielaborasikan dari berbagai aspek atau ditinjau dari berbagai perspektif mata pelajaran yang biasa diajarkan disekolah. Pembelajaran tematik adalah pembelajaran yang menggunakan tema dalam mengaitkan beberapa mata pelajaran sehingga dapat memberikan pengalaman bermakna kepada siswa (Effendi, 2009: 129). Trianto (2010: 78) menyatakan bahwa pembelajaran tematik dimaknai sebagai pembelajaran yang dirancang berdasarkan tema-tema tertentu, dalam pembahasan tema itu ditinjau dari berbagai mata pelajaran.

Pada pembelajaran tematik guru dituntut untuk lebih inovatif, mampu menciptakan pembelajaran yang menyenangkan, menciptakann rasa gembira peserta didik pada saat pembelajaran, mampu mengajak siswa untuk bereksplorasi langsung terhadap lingkungan sekitar. Untuk mencapai itu semua guru diminta untuk memliki gaya belajar yang menarik dan menantang bagi peserta didik.

Jadi seorang guru harus mampu memilih strategi belajar mengajar yang tepat untuk dapat menumbuhkan semangat dan minat siswa dalam belajar. Dalam kaitannya dengan belajar mengajar, strategi yang dimaksud sebagai daya upaya guru dalam menciptakan suatu sistem lingkungan yang memungkinkan terjadinya proses belajar mengajar yang berkenaan dengan segala persiapan pembelajaran agar proses pelaksanaan pembelajaran dapat berjalan dengan lacar dan tujuannya berupa hasil belajar bisa tercapai secara optimal.

Menurut Depdiknas (2006: 6), sebagai model pembelajaran diSekolah Dasar, pembelajaran tematik mempunyai karakteristik - karakteristik antara lain berpusat pada siswa (Student Centered), hal ini sesuai dengan pendekatan belajar modern yang lebih banyak menempatkan siswa sebagai subyek belajar, sedangakan guru lebih kepada fasilitator yaitu memberikan kemudahankemudahan kepada siswa untuk melakukan aktivitas belajar. Guru memberikan pengalaman langsung kepada siswa (Direct Experiences), dengan pengalaman langsung ini siswa dihadapkan pada suatu yang nyata (konkit) sebagai dasar untuk memahami halhal yang abstrak. Guru dapat menyajikan konsep dari berbagai mata pelajaran dalam suatu proses pembelajaran. Dengan demikian siswa mampu memahami konsep-konsep tersebut secara utuh. Hal ini iperlukan untuk membantu siswa dalam memecahkan masalahmasalah yang dihadapi dalam kehidupan sehari-hari.

Upaya untuk meningkatkan keberhasilan siswa dapat dilakukan cara perbaikan melalui proses pengajaran. Dalam perbaikan proses pengajaran ini peran guru sangat penting. Oleh karena itu guru harus mampu mencari strategi yang dipandang dapat membelajarkan siswa melalui proses pengajaran dapat tercapai secara efektif, dan hasil belajarpun diharapkan dapat lebih ditingkatkan.

Pembelajaran yang baik, menarik di dalam kelas adalah pembelajaran yang mampu menumbuhkan pemahaman siswa tentang konsep dan cara berpikir siswa. Dari sekian banyak model pembelajaran yang ada. Ada dua model pembelajaran yang banyak diadopsi untuk menunjang pendekatan pembelajaran yang efektif yaitu model pembelajaran TGT (Teams Games Tournament). Pembelajaran TGT (Teams Games Tournament) menurut Rusman (2012: 224) adalah salah satu tipe model yang beranggotakan 5-6 siswa yang memiliki kemampuan, jenis kelamin, dan suku atau ras yang berbeda. Sedangkan Saco (dalam Rusman, 2012: 224) mengatakan bahwa dalam TGT siswa memainkan permainan dengan anggota-anggota tim (kelompok) lain untuik memperoleh skor bagi tim mereka masingmasing. Pembelajaran kooperatif TGT (Teams Games Tournament) Slavin, 2007: 116-167) terdiri dari lima langkah, yaitu: penyajian kelas (class presentation), belajar dalam kelompok (teams), permainan (games), 
pertandingan (tournament), dan penghargaan kelompok (teams reognition). Didalam TGT siswa dibagi kedalam beberapa kelompok kecil yang anggota kelompoknya dipilih secara heterogen. Disini kelompok kecil ini akan belajar bersama-sama (teams) dan akan melakukan permainan (games) untuk menyelesaikan permasalahan, sedangkan tournament dilaksakan setelah pembelajaran selesai. Model pembelajaran TGT menerapkan sistem pemberian skors, dengan tujuan agar siswa semanagat belajar dan melatih siswa untuk berkompetisi dengan jujur.

Selain model TGT adalah model pembelajaran NHT (Numbered Head Together). Pembelajaran kooperatif tipe NHT atau penomoran berpikir Bersama merupakan jenis pembelajaran kooperatif yang dirancang untuk mempengaruhi pola interaksi peserta didik. Model kooperatif NHT dikembangkan oleh Spancer kagan, dkk (Ibrahim, 2000: 25) dengan melibatkan peserta didik dalam menelaah bahan yang tercangkup dalam suatu pelajaran dan mengecek pemahaman mereka terhadap isi pelajaran tersebut, pembelajaran NHT memberikan kesempatan kepada siswa untuk saling membagikan ide-ide dan mempertimbangkan jawaban yang paling tepat. Selain itu, juga dapat mendorong peserta didik untuk meningkatkan semangat kerjasama mereka.

Terkait pelaksanaan penelitian model TGT yang dilakukan oleh Wardani pada tahun 2016 dengan judul "Pengaruh kolaborasi model pembelajaran Kooperatif tipe TGT dan Kancing Gemerincing Terhadap Hasil belajar Matematika Kelas VII SMP Kristen Salatiga" menyimpulkan bahwa model pembelajaran TGT memberikan pengaruh terhadap hasil belajar matematika siswa kelas VII SMP Kristen Salatiga. Dilihat dari nilai rata-rata kelas kontrol 70.22 dan kelas eksperimen 83.35. Penelitian oleh Miroh, S Patonah, dan U Kaltsium pada tahun 2019 dengan judul "Pengaruh Model Pembelajaran Teams Games Tournamen (TGT) terhadap Kemampuan Kolaborasi Siswa di SMP N 5 Ungaran" dapat disimpulkan dari penelitian ini model Model Pembelajaran Teams Games Tournamen (TGT) memberikan pengaruh terhadap kemampuan kolaborasi, dilihat dari nilai rata- rata kelas Kontrol 76\% dan kelas Eksperimen $82 \%$.

Adapun terkait penerapan model pembelajaran NHT penelitian yang dilakukan oleh Eka Novrita Sari pada tahun 2013 dengan judul "Pengaruh Kolaborasi Model Pembelajaran Kooperatif Tipe Numbered Heads Together Dengan Pendekatan Pemecahan Masalah Terhadap Kemampuan Pemecahan Masalah Matematika Siswa MTS N Pekanbaru" dari penelitian ini dapat disimpulkan bahwa model model ini berpengaruh pada kemampuan pemecahan matematika siswa. Dapat dilihat dari rata-rata nilai kelas Kontrol 71,375 dan kelas Eksperimen 81,84. Penelitian selanjutkan yang dilakukan oleh Ani Zul Fatunisa, AA. Sujadi, dan Irham Taufiq pada thun 2020 dengan judul "Efektivitas Model Pembelajaran Numbered Head Together dan Think Pair Share terhadap Hasil Belajar Matematika" dari penelitian ini dapat disimpulkan model pembelajaran Numbered Head Together lebih efektiv dapat dilihat dari rata-rata nilai kelas NHT 81,59 dan nilai kelas TPS 76,06.

Berdasarkan penelitian yang sudah dilakukan pada Model Pembelajaran TGT dan NHT belum didapatkan hasil penelitian Efektivitas model pembelajaran TGT dan NHT terhadap peningkatan keterampilan kolaborasi siswa kelas 4 SD. Maka terdapat keragu-raguan peneliti antara model pembelajaran TGT dengan model pembelajaran NHT, manakah model pembelajaran yang lebih efektif untuk meningkatkan kemampuan keterampilan kolaborasi siswa dalam pembelajaran tematik.

Adanya peluang model pembelajaran untuk diitegrasikan dan untuk menghilangkan keraguan terhadap efektivitas model pembelajaran TGT dan NHT terhadap kemampuan keterampilan kolaborasi siswa kelas 4 SD. Menjadi dasar diangkatnya judul penelitian "Meta Analisis Efektivitas Model Pembelajaran TGT dan NHT terhadap Peningkatan Keterampilan Kolaborasi Siswa Kelas 4 SD”. Adapun treatment dalam penelitian ini dilakukan melalui pengolahan data terdahulu. 


\section{METODE PENELITIAN}

Jenis penelitian yang digunakan dalam penelitian ini adalah penelitian Meta-Analisis. Meta analisis merupakan penelitian yang menggunakan metode telaah yang disertai dengan Teknik statistic yang digunkan untuk menghitung kesimpulan dari beberapa hasil penelitian. Penelitian ini diambil dari beberapa jurnal artikel, ataupun buku sebagai sumber datanya. Menurut Wahyuningsih, Darmayanti, Binarti (2019: 33) "meta analisis merupakan suatu penelitian yang menganalisis berbagai penelitian yang mengarah pada pembahasan masalah yang sama untuk mendapatan kesimpulan yang bersifat umum dan secara luas. Metode penelitian yang digunakan dalam penelitian ini adalah meta analisis, analisis yang menguraikan sistematik yang mengaanalisis hasil penelitian yang sudah diterbitkan secara nasional yang berkaitan dengan penggunaan model pembelajaran TGT dan model pembelajaran NHT terhadap peningkatan keteterampilan kolaboras siswa. Penelitian ini bertujuan untuk mengetahui ada tidaknya perbedaan yang efektif anatara penggunaan model pembelajaran TGT dan NHT dalam peningkatan keterampilan kolaborasi siswa. Penelitian ini dilakukan di Program Studi Pendidikan Sekolah Dasar, Fakultas Keguruan dan Ilmu Pendidikan Universitas Kristen Satya Wacana, dengan hasil penelitian dalam bentuk jurnal nasional. Pelaksanaan penelitian ini dilakukan mulai dari bulan September sampai dengan bulan Desember.

Teknik yang digunakan adalah analisis Teknik Effect Size dengan rumus effect size yang digunakan formula pengeruh dengan rumus eta kuadrat (í2). Instrumen yang digunakan peneliti dalam penelitian ini insrtumen pemberian koding (coding data). variabel yang digunakan dalam memperoleh informasi mengenai besar pengaruh (effect size) penelitian meta-analisis.

\section{HASIL PENELITIAN DAN PEMBAHASAN \\ HASIL PENELITIAN}

Dari data artikel hasil yang diolah dengan cara merangkum atau komparasi dari model pembelajaran Teams Games
Tournamen TGT dan Numbered Head Together NHT yang kemudian dilaorkan Kembali. Berikut merupakan hasil komparasi model pembelajaran TGT dan NHT.

Table 1. Presentase Peningkatan Model

\section{TGT}

\begin{tabular}{|c|c|c|c|c|}
\hline \multirow[t]{2}{*}{ No } & \multirow{2}{*}{$\begin{array}{l}\text { Kode } \\
\text { Data }\end{array}$} & \multicolumn{3}{|c|}{ Presentase \% } \\
\hline & & Eksperimen 1 & Eksperimen 2 & Peningkatan \\
\hline 1 & A1 & 78,22 & 93,18 & 14,96 \\
\hline 2 & A2 & 70,22 & 83,35 & 13,13 \\
\hline 3 & $\mathrm{~A} 3$ & 76 & 82 & 6 \\
\hline 4 & A4 & 79,44 & 82,94 & 3,5 \\
\hline & ean & 75,97 & 85,36 & 9,39 \\
\hline
\end{tabular}

Menunjukan bahwa model pembelajaran TGT mampu meningkatkan keterampilan kolaborasi siswa sekolah dasar, dapat dilihat dari prenstase rata-rata peningkatan model pembelajaran TGT mulai dari yang terendah $3,5 \%$ dan yang tertinggi $14,96 \%$ dengan ratarata $9,39 \%$. Sedangkan pada tabel 7 menunjukan bahwa nilai presentase dari pembelajaran NHT nilai terendah $5,53 \%$ dan yang tertinggi $42,13 \%$ dengan rata-rata 2,49 nilai presentase model pembelajaran NHT lebih kecil dari model pembelajaran TGT.

Data hasil komparasi model pemeblajaran TGT dan NHT

Table 2. Presentase Peningkatan Model NHT

\begin{tabular}{|c|c|c|c|c|}
\hline \multirow[t]{2}{*}{ No } & \multirow{2}{*}{$\begin{array}{l}\text { Kode } \\
\text { Data }\end{array}$} & \multicolumn{3}{|c|}{ Presentase \% } \\
\hline & & Eksperimen 1 & Eksperimen 2 & Peningkatan \\
\hline 1 & B1 & 71,375 & 81,84 & 10,465 \\
\hline 2 & B2 & 50,29 & 92,42 & 42,13 \\
\hline 3 & B3 & 76,06 & 81,59 & 5,53 \\
\hline 4 & B4 & 57,20 & 72,07 & 14,87 \\
\hline & & 63,73 & 66,23 & 2,49 \\
\hline
\end{tabular}

penggunaan model pembelajaran TGT lebih tinggi dari pada model pembelajaran NHT. Hal tersebut dapat ditunjukan dari komparasi data berikut.

Berdasarkan data hasil komparasi ratarata dapat dilihat selisih rata-rata skor pembelajaran TGT adalah 9,39 dan selesih antara model pembelajaran NHT adalah 2,49. Berikut ini merupakan Diagram hasil komparasi model pembelajaran Teams Game Analisis Data Analisis Data dilakukan untuk mengetahui tingkat keefektifan Model pembelajaran terhadap peningkatan keterampilan kolaborasi. Analisis data yang dilakukan yaitu menggunakan Uji Prasyarat 
yang dilakukan melalui uji normalitas, uji homogenitas, dan uji linearitas. Uji prasyarat dilakukan sebelum melakukan uji Ancova. Uji Ancova dilakukan untuk mengetahui hasil pengaruh perbedaan model pembelajaran yang digunakan terhadap peningatan keterampilan kolaborasi siswa. Uji Prasyarat yang dilakukan adalah uji normalitas yang berdistribusi normal.

Tournamen (TGT) dan Numbered Head Together (NHT).

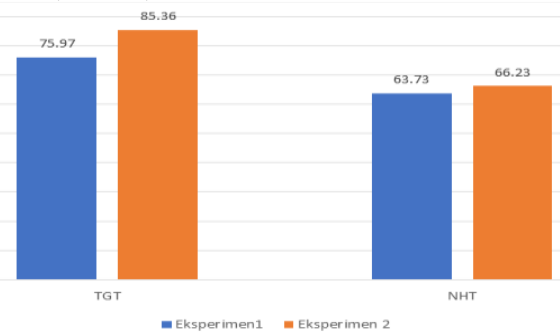

Gambar 1. Analisa Data Keefektifan Uji Normalitas

Uji normalitas merupakan uji yang dilakukan untuk mengetahui apakah sumber relevan atau tidak. Uji normalitas dalam penelitian ini menggunakan uji Teknik Shapiro-Wilk berbantuan SPSS 20.00 for Windows. Berikut merupakan tabel hasil uji normalitas kolaborasi skor pretest dan postest model pembelajaran TGT dan NHT.

Tabel 3. Uji Normalitas Model

Pembelajaran TGT dan NHT

\begin{tabular}{|c|c|c|c|c|c|c|c|}
\hline \multicolumn{8}{|c|}{ Tests of Normality } \\
\hline & \multirow[t]{2}{*}{ Kelas } & \multicolumn{3}{|c|}{ Kolmogorov-Smirnov } & \multicolumn{3}{|c|}{ Shapiro-Wilk } \\
\hline & & Statistic & $\mathrm{df}$ & Sig. & Statistic & df & Sig. \\
\hline \multirow{4}{*}{ Kolaborasi } & TGT Eksperimen 1 & .253 & & & .896 & 4 & .413 \\
\hline & TGT Eksperimen 2 & .400 & & & .730 & 4 & .025 \\
\hline & NHT Eksperimen 1 & .238 & & & .929 & 4 & .586 \\
\hline & NHT Eksperimen 2 & .321 & & & .849 & 4 & .225 \\
\hline
\end{tabular}

a. Lilliefors Significance Correction

Berdasarkan tabel diatas dapat disimpulkan bahwa uji normalitas kolaborasi skor Eksperimen 1 dan Eksperimen 2 dari model pembelajaran TGT dan NHT dapat dikatakan jika diperoleh nilai signifikan $<0,05$ maka data berdistribusi tidak normal dan jika nila Signifikan > 0,05 maka data berdistribusi normal. Tingkat signifikan skor Eksperimen 1 model pembelajaran TGT $0,413>0,05$ yang berarti nilai berdistribusi normal. Tingkat signifikan skor Eksperimen 2 TGT adalah $0,025>0,05$ artinya berdistribusi normal. Sedangkan tingkat signifikan skor Eksperimen 1 model pembelajaran NHT adalah 0,586 >
0,05 artinya berdistribusi normal. Tingkat skor Eksperimen 2 NHT adalah 0,225>0,05 artinya nilai berdistribusi normal.

\section{Uji Homogenitas}

Uji homogenitas dilakukan untuk mengetahui apakah sampel skor artikel dikumpulkan dari model pembelajaran TGT dan NHT memiliki varian yang sama. Dapat dikatakan homogen jika nilai signifikan $>0,05$ dan tidak homogen jika nilai signifikan $<0,05$. Berikut merupakan tabel uji Homogenitas skor Eksperimen 1 dan Eksperimen 2 Model pembelajaran TGT dan NHT Menggunakan SPSS 20.00 For Windowsw.

\section{Tabel 4. Uji Homogenitas Eksperimen 1 Model Pembelajaran TGT dan NHT}

\begin{tabular}{|c|c|c|c|c|c|}
\hline & & Levene Statistic & df1 & $\mathrm{df} 2$ & Sig. \\
\hline \multirow{4}{*}{ Kolaborasi } & Based on Mean & .571 & 1 & 6 & .478 \\
\hline & Based on Median & .507 & 1 & 6 & .503 \\
\hline & $\begin{array}{l}\text { Based on Median and with } \\
\text { adjusted df }\end{array}$ & .507 & 1 & 4.279 & .513 \\
\hline & Based on trimmed mean & .567 & 1 & & .480 \\
\hline
\end{tabular}

Tabel diatas menunjukan hasil uji homogenitas menggunakan Levene's Test. Interpretasi dilakukan dengan memilih salah satu statistic yang dilakukan dengan rata-rata (Based on Mean). Hasil uji homogenitas Eksperimen 1 memperoleh signifikasi 0, 478 $>0,05$ yang artinya model pembelajaran TGT dan NHT memiliki variasi yang sama atau Homogen.

Tabel 5. Uji Homogenitas Model Pembelajaran TGT dan NHT

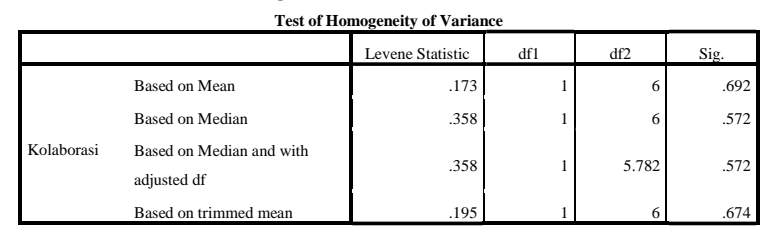

Tabel diatas menunjukan hasil uji homogenitas menggunakan Levene's Test. Interprestasi dilakukan dengan memilih salah satu statistic, yaitu statistic dengan rata-rata (Based on Mean). Nilai homogenitas dilihat dari hasil uji Homogenitas Eksperimen 2 memperoleh signifikasi yaitu 0,692 >0,05. Dapat disimpulkan bahwa model pembelajaran TGT dan NHT memiliki variasi yang sama atau homogen.

\section{Uji Linearitas}

Uji Linearitas ini merupakan uji untuk mengetahui apakah variable bebas menggunakan model pembelajaran TGT dan 
NHT terhadap variable terikat meningkatkan keterampilan kolaborasi mempunyai hubungan yang linear atau tidak secara signifikan. Dalam penelitian ini menggunakan Uji Linearitas berbantuan SPSS 20.00 for windows, berikut merupakan tabel uji linearitas skor Eksperimen 1 dan Eksperimen 2 model pembelajaran TGT.

Tabel 6. Uji Lineritas Skor Eksperimen 1 dan Eksperimen 2 model Pembelajaran TGT

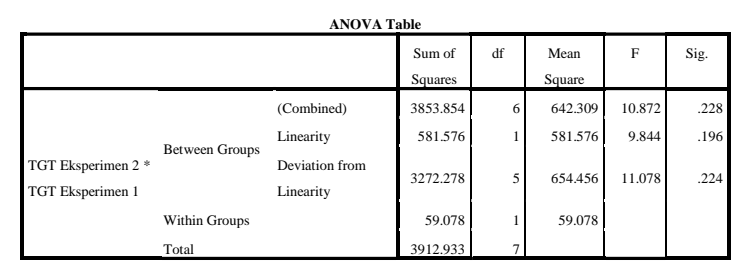

Berdasarkan tabel diatas dapat disimpulkan bahwa uji linearitas skor Eksperimen 1 dan Eksperimen 2 model pembelajaran TGT dilihat dari satu statistic, yaitu Deviation from Linearity, berdasarkan tabel diatas Eksperimen 1 dan Eksperimen 2 memperoleh signifikasi 0,224>0,05 artinya bahwa skor Eksperimen 1 dan Eksperimen 2 model pembelajaran TGT memiliki hubungan yang linear.

Tabel 7. Uji Lineritas Skor Eksperimen 1 dan Eksperimen 2 model Pembelajaran NHT

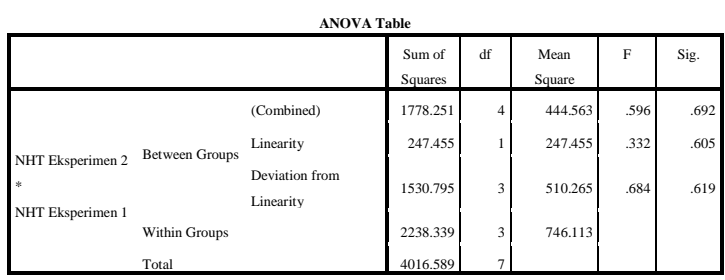

Berdasarkan tabel diatas dapat disimpulkan bahwa uji linearitas skor Eksperimen 1 dan Eksperimen 2 model pembelajaran NHT dilihat dari statistic, yaitu yang dilakukan dengan Deviation from Linearity, berdasarkan tabel diatas dilihat hasil uji linearitas Eksperimen 1 dan Eksperimen 2 memperoleh signifikasi 0,619>0,05 artinya skor Eksperimen 1 dan Eksperimen 2 model pembelajaran NHT memiliki hubungan yang linear.

\section{Uji Ancova}

Berdasarkan hasil uji normalitas, uji homogenitas, uji linearity, dapat disimpulkan bahwa data berdistribusi normal, homogen, dan linear. Setelah melakukan uji prasyarat dapat dilakukan uji Ancova dengan bebantuan SPSS 20.00 for windows. Uji Ancova ini dilakukan untuk mengetahui ada atau tidaknya perbedaan antara model pembelajaran TGT dan NHT terhadap peningkatan keterampilan kolaborasi siswa kelas SD. Berikut merupakan tabel hasil dari analisis uji Ancova.

Tabel 8. Hasil Analisis Data Menggunakan

\section{Uji Ancova}

Descriptive Statistics

Dependent Variable: Eksperimen 2

\begin{tabular}{|c|c|c|c|}
\hline Model Pembelajaran & Mean & Std. Deviation & N \\
\hline TGT & 85.3675 & 5.23890 & 4 \\
NHT & 63.7313 & 12.02427 & 4 \\
Total & 74.5494 & 14.40408 & 8 \\
\hline
\end{tabular}

Berdasarkan hasil analisis uji Ancova yang dilakukan pada model pembelajaran TGT dengan jumlah artikel 4 dengan rata-rata 85,3675 . Sedangkan pada model pembelajaran NHT dengan jumlah artikel 4 mempunyai ratarata 63.7313. sehingga terdapat perbedaan anatara model TGT dan model pembelajaran NHT dapat dilihat dari peningkatan kolaborasi pembelajaran tematik. Model pembelajaran TGT hasilnya lebih tinggi dari model pembelajaran NHT.

Tabel 9. Hasil Analisi Uji Ancova

Tests of Between-Subjects Effects

\begin{tabular}{|l|l|l|l|l|l|l|}
\hline Sependent Variable: Eksperimen 2 & $\begin{array}{l}\text { Type III Sum } \\
\text { of Squares }\end{array}$ & Df & $\begin{array}{l}\text { Mean } \\
\text { Square }\end{array}$ & F & Sig. & $\begin{array}{l}\text { Partial Eta } \\
\text { Squared }\end{array}$ \\
\hline Corrected Model & $936.255^{\mathrm{a}}$ & 1 & 936.255 & 10.885 & .016 & .645 \\
Intercept & 44460.875 & 1 & 44460.875 & 516.89 & .000 & .989 \\
Model_Pembelajaran & 936.255 & 1 & 936.255 & 10.885 & .016 & .645 \\
Error & 516.088 & 6 & 86.015 & & & \\
Total & 45913.217 & 8 & & & & \\
Corrected Total & 1452.342 & 7 & & & \\
a. R Squared = .645 (Adjusted R Squared $=.585$ )
\end{tabular}

Berdasarkan hasil uji Ancova yang terletak ada kolom model pembelajaran pada tabel diatas dapat disimpulkan pada kolom Sig. sebesar 0,016 dan $\mathrm{F}$ hitung yang diperoleh adalah 10,885 .

\section{Uji Hipotesis}

Setelah melakukan uji Ancova kemudian dilakukan uji hipotesis. Uji hipotesis dilakukan untuk mengetahui apakah hipotesis diterima atau ditolak. Berikut merupakan hipotesis penelitian:

Ha: Tidak terdapat perbedaan yang signifikan anatara penggunaan model pembelajaran 
TGT dan NHT ditinjau dari peningkatan keterampilan kolaborasi.

Ho: Terdapat perbedaan yang signifikan antara penggunaan model pembelajaran TGT dan NHT ditinjau dari peningkatan keterampilan kolaborasi.

Kriteria pengambilan keputusan:

1. Menggunakan koefisien Sig. dengan ketentuan:

a. Jika nilai Sig. hitung (Probabilitas) < 0,05 maka Ho ditolak dan Ha diterima.

b. Jika nilai Sig. hitung (Probabilitas) > 0,05 maka Ho diteima dan Ha ditolak.

2. Menggunakan koefisien thitung dengan ketentuan:

a. Jika koefisien $\mathrm{f}$ hitung $>\mathrm{f}$ tabel maka Ho ditolak dan Ha diterima.

b. Jika koefisien $\mathrm{f}$ hitung $<\mathrm{f}$ tabel maka Ho diterima dan Ha ditolak.

Berdasarkan hasil perhitungan hipotesis menggunakan uji Ancova menggunakan Univariete yang menunjukan bahwa nilai signifikansi sebesar 0,016 yang berarti lebih kecil dari $0,05(0,016<0,05)$. Dari uji Ancova menunjukan $\mathrm{f}$ hitung $>\mathrm{f}$ tabel yaitu $10,885>5,79$ dan signifikansinya 0,016 $<0,05$ yang menunjukan bahwa Ho ditolak dan Ha diterima. Dari hasil uji ini menunjukan bahwa terdapat perbedaan yang signifikan dalam penggunaan model pembelajaran TGT dan NHT dalam meningkatkan kterampilan kolaborasi siswa.

\section{Effect Size}

Effect Size (besaran efek) menunjukan perbedaan standar anatara skor dari model pembelajaran TGT dan NHT. Effect Size merupakan satuan standar yang artinya dapat dibandingkan dengan beberapa skala yang berbeda. Effect Size yang dapat digunkan dalam penelitian ini adalah Cohen' $\mathrm{S} d$, diartikan bahwa semakin besar nilainya maka semakin besar perbedaan antara model pembelajaran TGT dn NHT. Interpretasi Effect Size dapat dilihat sebagai berikut:

\section{Tabel 10. Hasil Uji Effect Size Menggunakan Ancova}

Tests of Between-Subjects Effects

Dependent Variable: Eksperimen 2
\begin{tabular}{|l|r|r|r|r|r|r|}
\hline Source & $\begin{array}{c}\text { Type III Sum of } \\
\text { Squares }\end{array}$ & df & \multicolumn{1}{c|}{$\begin{array}{c}\text { Mean } \\
\text { Square }\end{array}$} & F & Sig. & $\begin{array}{c}\text { Partial Eta } \\
\text { Squared }\end{array}$ \\
\hline Corrected Model & $936.255^{5}$ & 1 & 936.255 & 10.885 & .016 & .645 \\
Intercept & 44460.875 & 1 & 44460.875 & 516.899 & .000 & .989 \\
Model_Pembelajaran & 936.255 & 1 & 936.255 & 10.885 & .016 & .645 \\
Error & 516.088 & 6 & 86.015 & & & \\
Total & 45913.217 & 8 & & & & \\
Corrected Total & 1452.342 & 7 & & & & \\
\hline
\end{tabular}
a. R Squared =.645 (Adjusted R Squared $=.585$ )

Berdasarkan Tabel diatas dari hasil melakukan uji Effect Size menggunkan Uji Ancova pada model pembelajaran TGT dan NHT terdapat hasil pada kolom Correct Model yang diketahui Partical Eta Squared sebesar 0,645 dengan nilai Sig. 0,016. Dari hasil uji ini menunjukan bahwa model pembelajaran TGT dan Model pembelajaran NHT memberikan pengaruh yang tergolong sedang terhadap peningkatan keterampilan kolaborasi.

\section{PEMBAHASAN}

Penelitian ini dilakukan untuk mengetahui apakah terdapat perbedaan dari model pembelajaran TGT dan NHT terhadap peningkatan keterampilan kolaborasi siswa. Penelitian ini merupakan penelitian yang termasuk dalam jenis penelitian Meta Analisis. Tahapan awal yang dilakukan dalam penelitian ini adalah merumuskan masalah dan mengumpulkan data penelitian melalui jurnal elektronik. Berdasarkan hasil penelusuran peneliti mendapatkan 8 artikel yang relevan.

Presentase rata-rata peningkatan keterampilan kolaborasi pembelajaran TGT dari skor terendah $3,5 \%$ dan skor tertinggi $14,96 \%$ dengan rata-rata sebesar 9,39\%. Presentase rata-rata peningkatan keterampilan kolaborasi sebelum menggunakan model pembelajaran TGT sebesar 66,23\%. Presentase rata-rata peningkatan keterampilan kolaborasi sesudah menggunakan model pembelajaran TGT sebesar $85,36 \%$.

Presentase rata-rata peningkatan keterampilan kolaborasi dengn model pembelajaran NHT dari skor terendah 5,53\% dan skor tertinggi $42,13 \%$ dengan rata-rata sebesar 2,49\%. Presentase rata-rata peningkatan keterampilan kolaborasi sebelum menggunakan model pembelajaran NHT sebesar 63,73\% presentase sesudah menggunakan model pembelajaran NHT sebesar $66,23 \%$. 
Uji prasyarat model pembelajaran TGT dan NHT memiliki hasil normal, homogen dan linear. Uji homogen dapat dilihat dari Eksperimen 1 dari model pembeljaran TGT dan NHT menunjukkan Sig. sebesar 0,478 > 0,05, sedangnkan pada data Eksperimen 2 model pembelajaran TGT dan NHT menunjukan Sig. sebesar 0,692 >0,05. Dapat disimpulkan bahwa model pembelajaran TGT dan NHT berdistribusi homogen. Uji normalitas yang menggunakan Teknik Shapiro-Wilk menunjukan bahwa nilai Sig. > 0,05 sehingga dapat disimpulakan bahwa model pembelajaran TGT dan NHT berdistribusi normal. Uji linearitas dari Eksperimen 1 dan Eksperimen 2 model pembelajaran TGT yang dilakukan dengan Deviation from Linearity, nilai Sig. 0,224 > 0,05 dapat disimpulkan Eksperimen 1 dan Eksperimen 2 model pembelajaran TGT memiliki hubungan yang linear, sedangkan pada Eksperimen 1 dan Eksperimen 2 model pembelajaran NHT menunjukkan Sig. 0,619> 0,05 dapat disimpulkan Eksperimen 1 dan Eksperimen 2 model pembelajaran NHT memiliki hubungan yang linear.

Uji Ancova dengan SPSS 20.00 for windows dari hasil analisis data model pembelajaran TGT mendapatkan hasil sebesar 85,3675 sedangkan pada model pembelajaran NHT mendapatkan hasil sebesar 63.7313. selanjutnya hasil analisis pada uji Ancova nilai Sig. sebesar 0,016 dan f hitung yang diperoleh adalah 10,885 .

Uji Hipotesis menggunakan uji Ancova yang menggunakan Unvariate menunjukan $\mathrm{f}$ hitung $>\mathrm{f}$ tabel yaitu $10,885>$ 5,79 dan Sig. $0,016<0,05$ yang artinya Ho ditolak dan Ha diterima. Dari hasil uji hipotesis dapat disimpulkan bahwa terdapat perbedaan yang signifikansi dalam pengguanaan model pembelajaran TGT dan NHT dalam meningkatkan keterampilan kolaborasi siswa.

Effect Size menggunakan uji Ancova pada model pembelajaran TGT dan NHT dari hasil Correct Model yang diketahui Partical Eta Squared sebesar 0,645 dengan nilai Sig. 0,016. Dapat disimpulkan model pembelajaran TGT dan NHT memberikan pengaruh yang tergolong sedang. Berdasarkan hasil pengolahan data bahwa model pembelajaran
TGT memiliki skor tinggi dibandingkan dengan menggunakan model pembelajaran NHT.

\section{KESIMPULAN}

Berdasarkan hasil penelitian dan pembahasan yang sudah dibahas dan dijabarkan, maka dapat disimpulkan hasil penelitian menunjukan bahwa Model Pembelajaran Team Games Tournament (TGT) lebih efektif jika dibandikan dengan Model Pembelajaran Numbered Head Together (NHT) terhadap peningkatan keterampilan kolaborasi siswa. Hal ini dapat dilihat dari hasil uji Acova dari nilai ratarataskor Eksperimen 2 model pembelajaran TGT sebesar 85,3675 lebih tinggi dibandingkan dengan model pembelajaran NHT sebesar 63,7313. Dapat disimpulkan bahwa terdapat perbedaan dari kedua model pembelajaran tersebut.

Berdasarkan perhitungan pada Effect Size yang diketahui Partial Eta Squared sebesar 0,645 dengan nilai Sig. sebesar 0,016. Perhitungan hipotesis menggunakan uji Ancova menggunakan Unvariate yang menunjukan nilai Sig. sebesar 0,016 yang berarti lebih kecil dari $0,05(0,016<0,05)$. Dari hasil uji Ancova menunjukan uji $f$ hitung $>\mathrm{f}$ tabel sebesar 0,016 dan $\mathrm{f}$ hitung yang diperoleh sebesar 10,885, yaitu 10,885 > 5,79 dan Sig. 0,016 < 0,05 yang menunjukan bahwa Ho ditolak dan $\mathrm{Ha}$ diterima. Menunjukan bahwa terdapat perbedaan yang signifikan dalam penggunaan model pembelajaran TGT dan NHT dalam peningkatan keterampilan kolaborasi.

\section{SARAN}

Berdasarkan kesimpulan diatas diketahui bahwa model pembelajaran TGT lebih efektif dibandingkan dengan pembelajaran NHT dalam meningkatan keterampilan kolaborasi. Maka peneliti memberikan referensi agar model pembelajaran TGT dapat diterapkan dalam pembelajaran disekolah khususnya sekolah Dasar untuk meningkatkan Kerampilan Kolaborasi siswa. 


\section{UCAPAN TERIMAKASIH}

Penulis menyadari bahwa dalam proses penyusunan skripsi ini mendapat banyak dukungan, perhatian, bantuan dan juga bimbingan dari berbagai pihak, sehingga penulis dapat menyelsaikan Tugas Akhir ini. Untuk itu pada kesempatan ini penulis ingin mengucapkan terima kasih kepada:

1. Herry Sanoto, S.Si., M.Pd, selaku Dekan FKIP UKSW yang bertanggung jawab penuh atas terselengaranya pendidikan di Fakultas.

2. Dr Mawardi, M.pd selaku Kaprogdi dan Dosen Pembimbing Tugas Akhir yang sudah membimbing, memberi pengarahan, wawasan dan Ilmu yang bermanfaat.

3. Dr Wasitohadi, M.Pd, selaku wali studi yang sudah memberikan bimbingan dari awal hingga akhir perkuliahan.

4. Kedua Orang Tua (Daud dan Weni) yang selalu memberikan dorongan, serta doa dan semangat kepada penulis.

5. Adik-adik (Julita, Ronaldo, Santhi, dan Winda Natasha) yang juga turut mendoakan dan memberi semangat bagi penulis.

6. Saudara dan keluarga besar yang juga ikut memberikan dukungan kepada penulis.

7. Teman dekat Heni, Susi, Dita, Maria yang sudah memberikan dorongan dan semangat bagi penulis.Benyamin Franklin Engkang yang telah mendukung dan memberikan dorongan dan semangat bagi penulis dalam menyelesaikan Tugas Akhir.

8. Teman-teman RS16E terimakasih atas semua waktu yang telah kita lalui Bersama selama berada di UKSW.

9. Semua pihak yang tidak dapat penulis sebutkan satu persatu, terima kasih atas Doa, motivasi dan dukungannya.

10. Semoga Tuhan Yang Maha Esa memberikan balasan yang berlipat ganda kepada penulis dan semua pihak yang terlibat dalam penyelesaian skripsi ini. Dan semoga karya ini bermanfaat bagi pembaca atau pun peneliti berikutnya, Terima Kasih Tuhan Yesus Memberkati.

\section{DAFTAR PUSTAKA}

Amri, S. (2013). Pengembangan \& Model Pembelajaran Dalam Kurikulum
2013. Jakarta: PT. Prestasi Pustaka Karya.

Hamdayama, J. (2014). Model dan metode Pembelajaran Kreatif Berkarakter. Bogor: Ghali Indonesia.

Irene Bulu, N. I. (2019). Kolaborasi Model Pembelajaran Kooperatif Numbered Head Together dengan Media Mind Mapping Terhadap Keterampilan Sosial dan Hasil Belajar Siswa SMA (Slua) Saraswati 1 Denpasar. Jurnal Biologi Kontekstual (JBK) 1(2), 164181.

Istarani. (2011). 58 Model Pembelajaran Inovatif (Reverensi Guru Dalam Menentukan Model Pembelajarn). Medan: Media Persada.

Kemendikbud. (2016). Panduan Penilaian Untuk Sekolah Dasar. Jakarta: Kementerian Pendidikan dan Kebudayaan .

Khoer, M. (2019). Pengaruh Penerapan Model Pembelajaran Kooperatif Tipe Numbered Head Together (NHT) Terhadap Peningkatan Kemampuan Berpikir Kreatif Siswa. Equilibirium: Jurnal Penelitian Pendidikan dan Ekonomi 16 (02), 113-122.

Komalasari, K. (2010). Pembelajaran Kontekstual Konsep dan Aplikasi. Bandung: Refika Aditama.

Miroh Miroh, S. U. (2019). Pengaruh Model Pembelajaran Team Games Tournament (TGT) terhadap Kemampuan Kolaborasi Siswa di SMP N 5 Ungaran. In Seminar Nasional Lontar Physics Forum, (pp. 113-118).

Pindi Darma Hutama, S. A. (2019). Perbedaan Kemampuan Kolaborasi dan Hasil Belajar Matematika Siswa Kelas 4 SD Menggunakan Model Pembelajaran Numbered Head Together dan Teams Games Tournament. Edukatif: Jurnal Ilmu Pendidikan 1(2), 80-87.

Shoimin, A. (2014). 68 Model Pembelajaran Inovatif dalam Kurikulum 2013. Yogyakarta: Ar-RuzzMedia. 
Slavin, R. E. (2011). Cooperative Learning Teori, Riset dan Praktik. Bandung: Nusa Media.

Sugiyono. (2018). Metode Penelitian Pendidikan: Pendekatan Kuantitatif, Kualitatif,dan R\&D. Bandung: Alfabeta.

Suprijono, A. (2014). Cooperative Learning: Teori PAIKEM. Yogyakarta: Pustaka Pelajar.

Teladaningsih One, M. H. (2019). Implementasi Model Pembelajaran Teams Games Tournament Meningkatkan Keterampilan Kolaboratif Peserta Didik Kelas 4 Sd. Pendas: Jurnal Ilmiah Pendidikan Dasar 4(1), 17-30.

Trianto. (2011). Model Pembelajaran Terpadu, Konsep, Strategi dan Implementasinya dalam KTSP. Jakarta: Bumi Aksara.

Trianto. (2011). Model-model Pembelajaran Inovatif. Jakarta: Prestasi Pustaka. Majid, Abdul. 2014. Pembelajaran Tematik Terpadu. Bandung: Remaja Rosda Karya.

Trilling, F. a. (2009). 21st century skills: learning for life in our times. Jossey Bass: USA.

Zubaidah, S. (2018). Keterampilan Abad 21: Bagaimana Membelajarkan dan Mengasesnya. Prosiding, Seminar Nasional Pendidikan Biologi yang diselenggarakan oleh Prodi Pendidikan Biologi FKIP Universitas Islam Riau, tanggal 28 April 2018. Riau: Universitas Islam Riau. 